\title{
Changes in thyroid status of Menidia beryllina exposed to the antifouling booster irgarol: Impacts of temperature and salinity
}

\author{
Lucas Buruaem Moreira a, b, *, Graciel Diamante ${ }^{\text {b }}$, Marissa Giroux ${ }^{\text {b }}$, Elvis Genbo Xu ${ }^{\text {b }}$, \\ Denis Moledo de Souza Abessa ${ }^{a}$, Daniel Schlenk ${ }^{b}$ \\ a Institute of Biosciences, São Paulo State University, São Vicente, SP, Brazil \\ ${ }^{\mathrm{b}}$ Department of Environmental Sciences, University of California Riverside, Riverside, CA, USA
}

\section{H I G H L I G H T S}

- Thyroid effects of irgarol assessed in Menidia beryllina.

- Condition factor of $M$. beryllina affected by irgarol.

- Thyroid targets of irgarol affected by temperature and salinity.

- Potential Adverse Outcome Pathway for irgarol is provided.

\section{A R T I C L E I N F O}

\section{Article history:}

Received 29 March 2018

Received in revised form

1 June 2018

Accepted 24 June 2018

Available online 26 June 2018

Handling Editor: Jim Lazorchak

\section{Keywords:}

Biocides

Climate change

Estuary

Endocrine disrupting chemicals

Fish endocrinology

Inland silversides

\section{G R A P H I C A L A B S T R A C T}

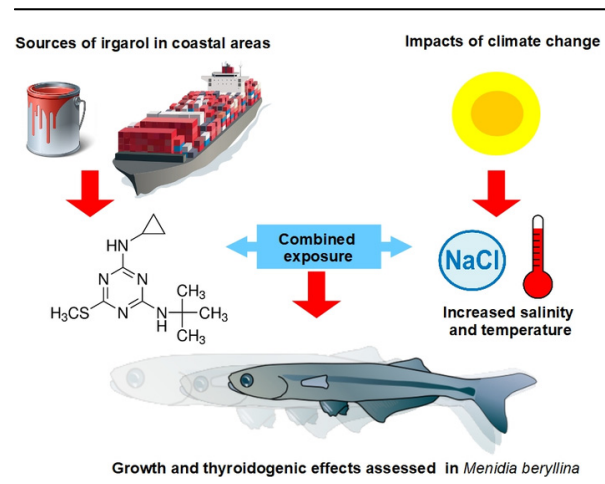

\begin{abstract}
A B S T R A C T
The triazine-based herbicide irgarol is widely used in antifouling systems as an algicide and has been detected recently in multiple coastal environments. Studies evaluating sub-lethal responses of fish following exposure to irgarol are limited. Moreover, impacts of climate change on fish endocrinology may also contribute to the sublethal toxicity of irgarol. We assessed the effects of irgarol on thyroid endpoints in juveniles of Menidia beryllina under two different treatments of salinity (10 and $20 \%$ ) and two temperatures $\left(10\right.$ and $\left.20^{\circ} \mathrm{C}\right)$. Condition factor coefficients $(\mathrm{K})$ of animals were significantly affected by 0.1 to $10 \mu \mathrm{g} / \mathrm{L}$ of irgarol at the higher temperature. Levels of T3 were changed in whole body homogenates from both temperatures at $10 \%$ following exposure to 1 to $10 \mu \mathrm{g} / \mathrm{L}$. T4 levels were altered only at $10^{\circ} \mathrm{C}$ when animals were treated with 1 to $10 \mu \mathrm{g} / \mathrm{L}(10 \%)$, and in 0.1 and $10 \mu \mathrm{g} / \mathrm{L}(20 \% 0)$. Increased transcripts of deiodinase enzymes at $10^{\circ} \mathrm{C}$ may be impacted by salinity and alter thyroid hormone homeostasis. Impact on gene expression of thyroid ( $\alpha$ and $\beta$ ) and growth hormone receptors were also determined. Our results highlight the relevance of environmental variable that may impact the ecological risk of irgarol in estuarine systems.
\end{abstract}

๑) 2018 Elsevier Ltd. All rights reserved.

\footnotetext{
* Corresponding author. Institute of Biosciences, São Paulo State University, Pça. Infante D. Henrique, São Vicente, 11330-900 Brazil.

E-mail addresses: lburuaem@gmail.com, lucas.buruaem@pq.cnpq.br (L.B. Moreira).
}

\section{Introduction}

Antifouling compounds are used in coating systems to prevent biocorrosion and unwanted development of biofouling on man- 
made surfaces including boats, vessels, off-shore formation and other constructions in aquatic environments (Chambers et al., 2006; Thomas and Brooks, 2010). Due to regulatory restrictions of organotin paints (OT), the use of OT-free antifouling systems has increased as an alternative to reduce the toxicity of antifouling systems to non-target organisms (Hall et al., 2009). Such paints contain biologically active compounds known as "organic boosters', which includes different biocides that are incorporated into the coating formulation formulations (Mochida and Fujii, 2009).

Since the mid-1980s the triazine-based herbicide irgarol (2methylthio-4-tert-butylamino-6-cyclopropylamino-s-triazine) has been widely used in antifouling systems as an algaecide (Hall et al., 2009; Mochida and Fujii, 2009). Since usage has increased, detection of irgarol has been observed in coastal environments (Bao et al., 2013). Irgarol is the most common detected antifouling booster worldwide, with environmental concentrations ranging from $<1 \mathrm{ng} / \mathrm{L}$ to $1 \mu \mathrm{g} / \mathrm{L}$ (Konstantinou and Albanis, 2004). In Southern California for example, levels of irgarol in water were measured up to $254 \mathrm{ng} / \mathrm{L}$ in sites nearby recreational marinas (Sapozhnikova et al., 2013). Irgarol has a reported half-life of 100-350 days ( $7 \pm 3$ days for estuarine waters), with moderate water solubility $(7 \mathrm{mg} / \mathrm{L})$ and lipophilicity $\left(\log \mathrm{K}_{\mathrm{ow}}=3.95\right)$ (Thomas et al., 2002; Konstantinou and Albanis, 2004; Sapozhnikova et al., 2009, 2013).

The mode of action of irgarol is similar to other triazine herbicides, in that it blocks electron transport during photosynthesis by inhibiting the energy transfer of photosystem II (PSII), reducing both $\mathrm{CO}_{2}$ uptake and carbohydrate production, which causes the starvation of the plant (Ebert et al., 1976). The toxicity of irgarol in estuarine and marine organisms is well documented in the literature and most studies have focused on acute and chronic effects endpoints in bioassays for algae, invertebrates and fish (Konstantinou and Albanis, 2004; Bao et al., 2011; Castro et al., 2011; Perina et al., 2011; Mai et al., 2013). However, studies on sub lethal effects are limited with one study showing immunosuppression in the ascidian Botryllus schlosseri (Cima and Ballarin, 2012) and changes in the fatty acid composition of Asian sea-bass Lates calcarifer (Ali et al., 2015). Regarding endocrine responses, the anti-estrogenic activity of irgarol was reported using a yeastbased in vitro assay (Westlund and Yargeau, 2017). Recent studies demonstrate that the antifouling booster diuron, which also acts in PSII, affect the thyroid system, growth, and development of aquatic organisms, including tadpoles American bullfrog Lithobates catesbeianus and the estuarine fish Menidia beryllina (Freitas et al., 2016; Moreira et al., 2018).

Silversides from the species $M$. beryllina, are the most common fish originated from West Atlantic inhabiting coastal environments from marshes to estuaries, and was introduced to Pacific coastal ecosystems (Middaugh and Hemmer, 1992). The species is a secondary consumer feeding on zooplankton and represents an important link in the marine food web as a prey item of other fish from higher links (Gleason and Bengtson, 1996). M. beryllina is also a eurythermic (tolerance range from 2.9 to $30^{\circ} \mathrm{C}$ ) and euryhaline (tolerance range from 0 to 35\%o) (USEPA, 2002), and recently it has been selected as a model for estuarine fish in the assessment of endocrine disrupting chemicals (EDCs) in coastal zones (Brander et al., 2016; Cole et al., 2016).

Shifts in environmental conditions including those induced by climate change events can also affect the toxicity of contaminants (Schiedek et al., 2007; Keller et al., 2015). In California's San Francisco Estuary-Watershed (SFEW) for example, climate change projections indicate extreme conditions of summers and winters (Cloern et al., 2011; Wagner et al., 2011). Such models project the decrease of freshwater input combined with seawater intrusion, as a result of sea level rising, increasing thus water temperature and salinity in the estuarine system. Considering this scenario, we assessed the effects of irgarol on thyroid function of estuarine fish using $M$. beryllina as a model under two conditions of temperature and salinity. Thyroid hormone (TH) endpoints were evaluated in juveniles and genes involved in TH pathways such as deiodinases enzymes (Dio1 and Dio3), growth (GHR) and thyroid hormone receptors (TR $\alpha$ and TR $\beta$ ) and were evaluated in fish's body homogenates following treatments. Molecular responses were combined to condition factor to determine if an Adverse Outcome Pathway could be formulated for irgarol.

\section{Materials and methods}

\subsection{Animals and experimental design}

We used sexually immature juveniles with 50 days of age, with $11.42 \pm 1.27 \mathrm{~mm}$ length and $0.016 \pm 0.006 \mathrm{~g}$ of weight. Animals were obtained from commercial cultures (Aquatic BioSystems Inc., Fort Collins, CO) and kept for 10 days of acclimation in experimental conditions of control preceding the experiments:10\% of water salinity, $10^{\circ} \mathrm{C}$ of temperature and photoperiod of $12: 12 \mathrm{~h}$ light:dark. Fish were fed brine shrimp nauplii once per day at 5:00 p.m. (USEPA, 2002). After the 10-day acclimation period, a semi-static exposure was performed at $10^{\circ} \mathrm{C}$ to evaluate the thyroidogenic effects of irgarol in M. beryllina. We tested two factors in each exposure: (I) salinity: $10 \%$ and $20 \%$, in order to assess salinity changes in oligohaline waters and (ii) irgarol: solvent control and three concentrations $(0.1,1$ and $10 \mu \mathrm{g} / \mathrm{L})$. Such concentrations were selected based on levels detected in samples from marinas of Southern California and other areas of East Coast from Florida to North Carolina (Hall et al., 2005; Sapozhnikova et al., 2013). Three months later, a new batch of fish with 50 days of age was purchased and a second exposure was performed at $20^{\circ} \mathrm{C}$ with the same salinities and levels of irgarol, based on variations in estuarine conditions tolerated by estuarine fish and temperature changes predicted by SFEW models (Cloern et al., 2011).

Analytical grade irgarol (Sigma-Aldrich) was purchased for preparing stock solutions in ultra-pure water and using $0.01 \%$ $\mathrm{MeOH}$ as a solvent. Irgarol exposure systems were assembled in $4 \mathrm{~L}$ tanks settled in a water bath (100 L capacity) with control of temperature performed via water-cooled chillers connected to thermostats. Sea salt aliquots were dissolved in dechlorinated water to achieve the selected salinity and then irgarol at nominal concentrations was added in a final volume of 3L. Two tanks per treatment were set up and kept in a cycle of $12-12 \mathrm{~h}$ (light-dark) with constant aeration. Following the 10 days of acclimation, 10 fish per tank were assigned to the respective treatment and exposed to irgarol for 15 days. Fish were fed on brine shrimp nauplii once per day at 5:00 p.m. at least $2 \mathrm{~h}$ preceding the water changes (90\% of total volume), which were performed every $48 \mathrm{~h}$. Water $\mathrm{pH}(7.5 \pm 0.5)$ and $\mathrm{NH} 3$ (below $0.01 \mathrm{mg} / \mathrm{L}$ ) were monitored before water changes. No changes in feeding rate or mortality were observed during the experimental exposures and after that, fish were euthanized using $300 \mathrm{mg} / \mathrm{L}$ of tricaine methanesulfonate (MS-222). Measurements of total length and wet weight were recorded and animals were frozen on liquid nitrogen to be stored at $-80^{\circ} \mathrm{C}$ until the analysis. These procedures followed the Animal Use Protocol (AUP), approved by UC Riverside Institutional Animal Care and Use Committee (IACUC). 


\subsection{Condition factor and hormone concentration analysis}

Condition factor $(\mathrm{K})$ was applied as the index of fish health following the exposure to irgarol. The equation $K=W / L^{b}$, indicated for allometric growth was selected using measurements of weight $(\mathrm{W})$, length $(\mathrm{L})$ and the constant $\mathrm{b}(0.14)$, obtained from the slope of W x L regression of acclimated fish (Bolger and Connolly (1989).

Levels of triiodothyronine (T3) and thyroxine (T4) were determined in homogenates of individual fish selected from each treatment $(\mathrm{n}=5)$ by enzyme-linked immunosorbent assay (ELISA) using specific kits (GenWay Biotech Inc., San Diego). For this analysis, a lysis solution was prepared containing Tris-Base $(50 \mathrm{mM})$, Deoxycholate (0.5\%), EDTA ( $1 \mathrm{mM}), \mathrm{NaCl}(50 \mathrm{mM}), \mathrm{SDS}(0.1 \%)$ and PMSF (1 mM). The buffer was added to each fish (1:5 dilution) to a subsequent incubation for $30 \mathrm{~min}$ at $4^{\circ} \mathrm{C}$. Then, tissue samples were disrupted using a mechanical homogenizer, centrifuged for $20 \mathrm{~min}$ $\left(15,000 \mathrm{~g}\right.$ at $\left.4^{\circ} \mathrm{C}\right)$ and the supernatant separated and stored at $-20^{\circ} \mathrm{C}$. The extracts were diluted again during the assay to fit the respective standard curves, ranging from 0 to $7.5 \mathrm{ng} / \mathrm{mL}$ of $\mathrm{T} 3$ and 0 to $250 \mathrm{ng} / \mathrm{mL}$ of T4. The intra-assay coefficient of variability (CV) of T3 duplicates was calculated at $7.62 \%$ and 9.26 for T4 $(n=100)$. Inter-assay CV was estimated from control samples in each plate $(\mathrm{n}=3)$ and were $10.93 \%$ for T3 and $11.73 \%$ for T4. Both levels were expressed in $\mathrm{ng} / \mathrm{g}$ of wet weight after the normalization by the weight of fish.

\subsection{Gene expression}

For mRNA measurements, whole body total RNA was isolated from individual fish per treatment $(n=5)$ by using Qiazol and the purification kit RNeasy Mini ${ }^{\mathbb{B}}$ that doesn't require DNase treatment (Qiagen, Germany). The purity and concentration of RNA were checked in a spectrophotometer (NanoDrop ${ }^{\circledR}$, Technologies Inc.) and the synthesis of cDNA was performed following the Quick Protocol A3500 (Promega Reverse Transcription System kit, Wisconsin, USA).

Quantitative polymerase chain reaction (qPCR) was conducted using a CFX Connect ${ }^{\mathbb{B}}$ (Bio-Rad) Real-Time PCR Detection System. Primers were designed for $M$. beryllina using Primer Quest platform (www.idtdna.com) based on sequences provided by Brander et al. (2016) (Table 1). The qPCR protocol included the reaction mixture containing the binding dye SsoAdvanced Universal SYBR ${ }^{\circledR}$ (Bio-Rad, Hercules, CA). The parameters for qPCR were fixed as $0.5 \mathrm{~min}$ $\left(95^{\circ} \mathrm{C}\right)$ followed by 40 cycles of $10 \mathrm{~s}\left(95^{\circ} \mathrm{C}\right)$ and 30 s for the steps of annealing and elongation $\left(55^{\circ} \mathrm{C}\right)$. The comparative delta-delta model $\left(\Delta \Delta C_{t}\right)$ proposed by Pfaffl (2001) was used to determine relative gene expression, based in the fold-differences of threshold cycle values $\left(C_{t}\right)$ between the target gene and housekeeping genes.
The efficiency of target genes was used to normalize the relative fold changes, expressed as the ratio of gene expression of each exposure group relative to its respective group of vehicle control.

\subsection{Data analysis}

Results of $\mathrm{K}$, hormone analysis and gene expression were assessed by Shapiro-Wilk's and Cochran's tests for normal distribution and homoscedasticity, respectively. For $\mathrm{K}$, the confidence interval $(\mathrm{CI})$ range was estimated in 5 to $95 \%$ and outliers were excluded by interquartile range criteria (Tukey, 1977). Results from the two tanks were analyzed by $t$-test aiming to determine the possible influence of pseudoreplication and no significant effects were observed. Then, each fish was considered as sampling unit and for each temperature experiment, we analyzed significant effects of irgarol levels versus salinity. Responses from K and ELISA were tested using a two-way ANOVA with fixed factors and four levels of exposure $(0.01 \% \mathrm{MeOH}, 0.1,1$ and $10 \mu \mathrm{g} / \mathrm{L}$ of irgarol $)$ and two levels for salinity (10\%o and 20\%o). Bonferroni method of multiple comparisons was used to test differences in $\mathrm{K}$ results from different treatments due to a different $n$. Dunnett's test was used for ELISA and qPCR results to compare the responses observed in the exposure groups with its respective solvent control $(\alpha=0.05)$.

\section{Results and discussion}

Results of K are presented in Fig. 1. Significant decreases in K were observed at $10{ }^{\circ} \mathrm{C}$ and $10 \%$ for 0.1 and $10 \mu \mathrm{g} / \mathrm{L}$ irgarol, with no interaction found between salinity and compound $(p=0,45)$. At $20 \%$, irgarol affected the $\mathrm{K}$ of fish in the $0.1 \mu \mathrm{g} / \mathrm{L}$ treatment. At the condition of higher temperature $\left(20^{\circ} \mathrm{C}\right)$, the interaction of irgarol and salinity $(\mathrm{p}=0.0008)$ decreased $\mathrm{K}$ of animals exposed in all treatments $(10 \%$ and $20 \%$ ). The herbicide diuron, which is also an inhibitor of PSII, impaired the growth and K of M. beryllina (Moreira et al., 2018). These findings corroborate our results indicating that irgarol produced responses on growth and they are consistent with effects induced by other triazine compounds in other aquatic vertebrates. Tadpoles of Silurana tropicalis chronically exposed for 28 days to $7 \mathrm{~s}$-triazines: ametryn $(0.2 \mathrm{mg} / \mathrm{L})$, prometryn $(0.25 \mathrm{mg} / \mathrm{L})$, dimethametryn $(0.03$ and $0.3 \mathrm{mg} / \mathrm{L})$, simazine $(0.8 \mathrm{mg} / \mathrm{L})$, atrazine $(0.1$ and $1 \mathrm{mg} / \mathrm{L})$, propazine $(0.1$ and $1 \mathrm{mg} / \mathrm{L})$, and cyanazine $(0.05$ and $0.5 \mathrm{mg} / \mathrm{L}$ ) exhibited reduced growth assessed by total length and body mass, and delayed developmental stages (Saka et al., 2018). In fish, juveniles of Atlantic salmon (Salmo salar) exposed for 21 days to $100 \mu \mathrm{g} / \mathrm{L}$ of atrazine had a significant reduction of feeding rate and growth (Nieves-Puigdoller et al., 2007). In contrast, 90 days of exposure to environmental concentrations of simazine $(0.06-4 \mu \mathrm{g} / \mathrm{L})$ did not affect the length, body weight and

Table 1

Primer sequences of genes assessed in M. beryllina by qPCR analysis.

\begin{tabular}{|c|c|c|c|c|c|}
\hline Gene & Symbol & Function & Amplicon length & Efficiency (\%) & Primer sequence \\
\hline 60s ribosomal protein 17 & RPL7 & Reference & 76 & 92 & $\begin{array}{l}F-\text { aacttcttgtggccgttcaag } \\
R-\text { tcgcctccctccacaaagt }\end{array}$ \\
\hline Thyroid hormone receptor alpha & $\operatorname{TR} \alpha$ & Hormone receptor & 51 & 94 & $\begin{array}{l}\mathrm{F} \text { - tgtcggacgccatattcgat } \\
\mathrm{R} \text { - cctcggtgtcatccaagttga }\end{array}$ \\
\hline Thyroid hormone receptor beta & $\operatorname{TR} \beta$ & Hormone receptor & 108 & 90 & $\begin{array}{l}\text { F - cgaagggaagtgcgttatc } \\
R \text { - ctgtcatccaacaccaagtc }\end{array}$ \\
\hline Growth hormone receptor beta & GHR & Hormone receptor & 60 & 90 & $\begin{array}{l}\mathrm{F} \text { - tcaagaaaggcaagcttcgag } \\
\mathrm{R} \text { - cggccttaaatcaagaggacc }\end{array}$ \\
\hline Iodothyronine deiodinase type I & Dio1 & Thyroid hormone metabolism & 217 & 91 & $\begin{array}{l}\text { F - cttgccagaagaggctattac } \\
\text { R - ggaagaactgactcccattg }\end{array}$ \\
\hline Iodothyronine deiodinase type III & Dio3 & Thyroid hormone metabolism & 205 & 90 & $\begin{array}{l}\mathrm{F} \text { - gcatctctgactccaacaag } \\
\mathrm{R} \text { - gagcagctgccaaagtta }\end{array}$ \\
\hline
\end{tabular}


A

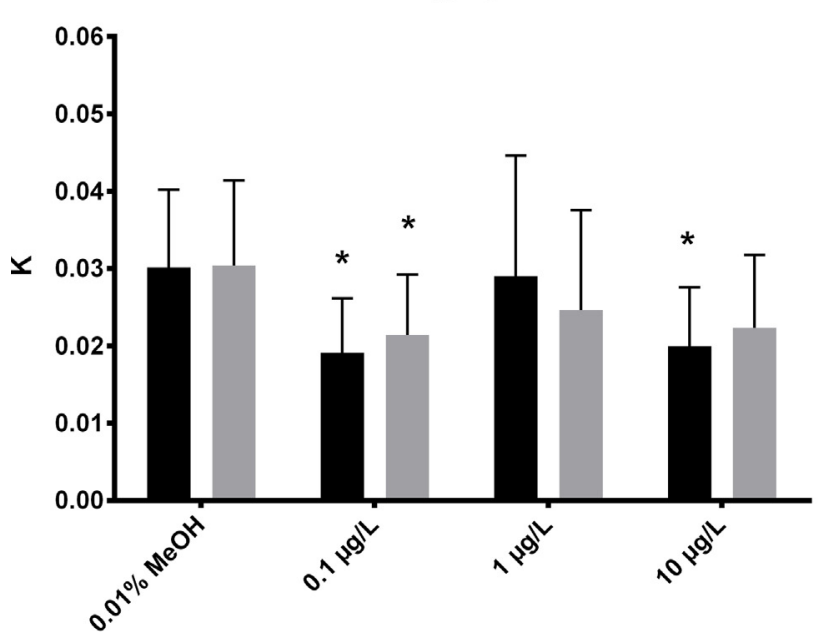

B

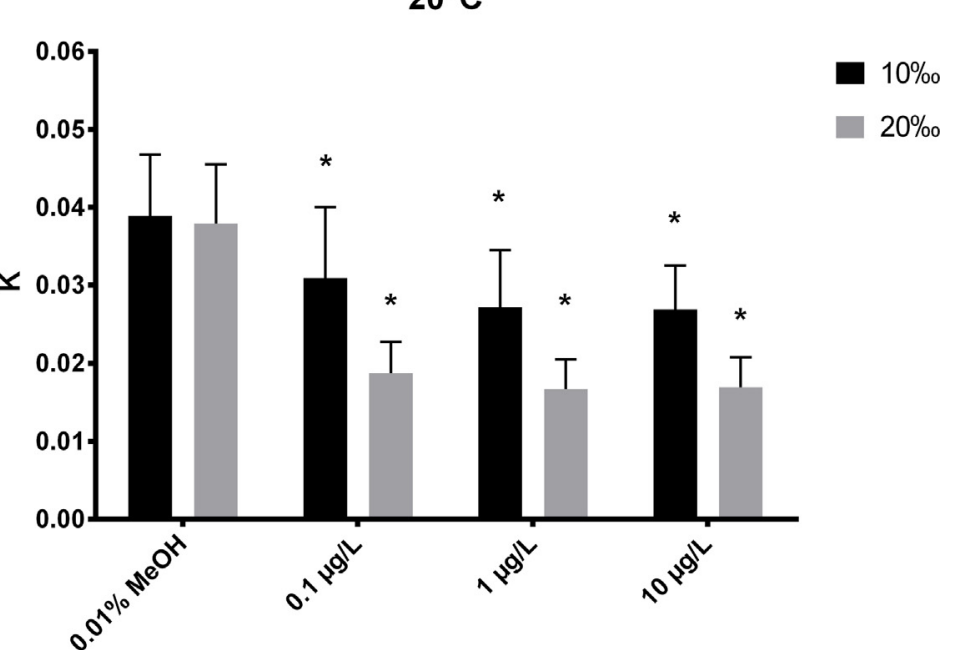

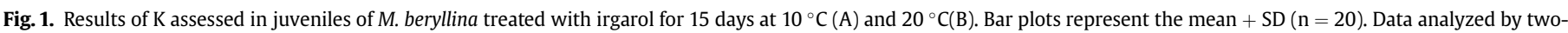
way ANOVA followed by Bonferroni's test comparing each group with control ( $\left.{ }^{*} \mathrm{p}<0.05\right)$.

Fulton's condition factor of one-year-old common carp Cyprinus carpio L. (Velisek et al., 2012a). For the same species, fertilized eggs exposed for 36 days to a range of $0.2-2 \mathrm{mg} / \mathrm{L}$ of terbutryn exhibited delayed larval development and decreased in condition factor (Velisek et al., 2012b).

The early development of the central and peripheral nervous system, the control of growth and basal metabolism in juveniles fish are regulated by actions of THs (Power et al., 2001). The combined influence of ontogenic development with environmental conditions stimulate the hypothalamus to release thyrotropinreleasing hormone (TRH) which controls the pituitary release of thyroid stimulating hormone (TSH) (MacKenzie et al., 2009). TSH causes the thyroid glands to produce T4, which is activated into T3 form by deiodinases (Power et al., 2001; Blanton and Specker, 2007; Jarque and Piña, 2014).

In the present investigation, the function of HPT axis was evaluated by TH levels in homogenates of $M$. beryllina treated with irgarol. At $10^{\circ} \mathrm{C}$ the effects were more pronounced and significant interactions were observed between compound and salinity ( $\mathrm{p}=0.0001$ for T3 and T4). Fish exposed at $10 \%$ presented high levels of T3 in $1 \mu \mathrm{g} / \mathrm{L}$ while T4 increased in the 1 and $10 \mu \mathrm{g} / \mathrm{L}$ treatments. Exposure at $20 \%$ increased the content of T3 in animals from all exposures and T4 increased significantly in 0.1 and $10 \mu \mathrm{g} / \mathrm{L}$. Higher temperature resulted in elevated levels of T3 only in animals treated with 1 and $10 \mu \mathrm{g} / \mathrm{L}$ of irgarol at $10 \%$ (significant interaction, $\mathrm{p}=0.0001$ ) and no changes in T4 levels were found (Fig. 2). Similar effects of enhanced T3 and T4 were reported in M. beryllina exposed to diuron at the same conditions temperature and salinity (Moreira et al., 2018), indicating that both photosynthetic inhibitors impact TH homeostasis.

Environmental variables including water temperature and salinity are important to regulate metabolism and osmoregulatory responses of estuarine fish by the action of THs (Peter, 2011). Elevated levels of T4 were reported in the climbing perch Anabas testudineus acclimated in higher salinity for 7 days (Rejitha et al., 2009). For the same species, Peter et al. (2011) described a modulatory mechanism of salinity stimulating T3 activation regulating thus the activity of $\mathrm{Na}^{+}, \mathrm{K}^{+}$-ATPase in gill as a consequence of the hyperosmotic condition. Regarding the effects of triazine compounds on TH regulation, juveniles of S. salar treated with 100 $\mu \mathrm{g} / \mathrm{L}$ of atrazine for 21 days at $10^{\circ} \mathrm{C}$ were submitted to hyperosmotic stress (freshwater to saltwater, 30\%o) and exhibited a significant increase in plasma cortisol, $\mathrm{Cl}^{-}, \mathrm{Mg}^{2+}, \mathrm{Na}^{+}, \mathrm{Ca}^{2+}$ followed by a decrease in $\mathrm{T} 4$ and $\mathrm{T} 3$, indicating effects on ionoregulatory response and inhibition of TH by atrazine (Nieves-Puigdoller et al., 2007).

Temperature also influenced the effects of irgarol on TH by increasing T3 at 10\%o. The activation of T4 into T3 occurs via deiodinase enzymes type I or type 2 (Dio1 and Dio2). T4 and T3 are inactivated and converted into rT3 and T2 (3,3'-diiodothyronine) by Dio1 and Dio3, respectively. Dio1 and Dio 2 transform rT3 in T2 (Orozco and Valverde, 2005; Jarque and Piña, 2014). We also assessed the transcripts of genes involved in TH deiodination in $M$. beryllina from treatments related to environmentally relevant levels of irgarol $(0.1$ and $1.0 \mu \mathrm{g} / \mathrm{L})$. Expression of Dio1 increased in all temperatures at $10 \%$. The combination of irgarol at higher salinity (20\%0) resulted in a $4-5$-fold increase in the expression of deiodinase type 3 (Dio3) (Fig. 3). Treatments at $20^{\circ} \mathrm{C}$ changed the expression in $10 \%$ treatments by increasing the fold change of Dio 1 in 0.1 and $1.0 \mu \mathrm{g} / \mathrm{L}$ of irgarol in up to two orders of magnitude compared to $10^{\circ} \mathrm{C}$, indicating a temperature effect combined with the herbicide in such response. The decreased expression for Dio 1 and Dio3 was observed in $20 \%$ treatments at $0.1 \mu \mathrm{g} / \mathrm{L}$ and $1 \mu \mathrm{g} / \mathrm{L}$, respectively (Fig. 4).

An induced activity of deiodinase was found associated with the somatic growth of the Atlantic cod Gadus morhua kept for 10 months at the increased temperature from 2 to $4^{\circ} \mathrm{C}$ (Cyr et al., 1998). The importance of TH function on thermal acclimation was also described in zebrafish (Danio rerio) acclimated in warm water compared with animals acclimated to cold water (Little et al., 2013). Previously studies have reported the higher expression of Dio1 and Dio3 in larval stage of killifish Kryptolebias marmoratus (Kang et al., 2017), zebrafish embryos (Dong et al., 2013) and Gobiocypris rarus (Chen et al., 2017) treated with the BDE-47 and 2,4-dichloro-6nitrophenol (DCNP). For M. beryllina, diuron induced the expression of Dio3 in combination with higher salinity, and the expression of Dio1 was also increased as a response to higher temperature (Moreira et al., 2018). In the current study, the augmented levels of 


\section{$10^{\circ} \mathrm{C}-\mathrm{T} 3$}

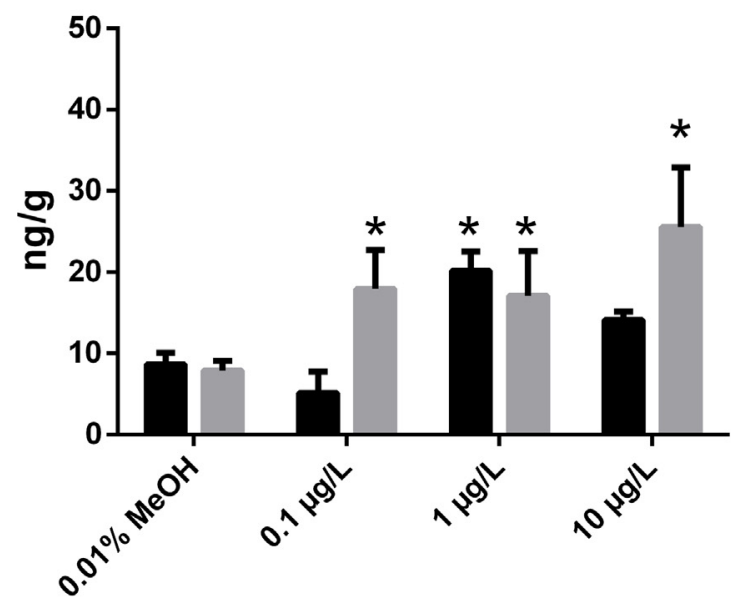

$10^{\circ} \mathrm{C}-\mathrm{T} 4$

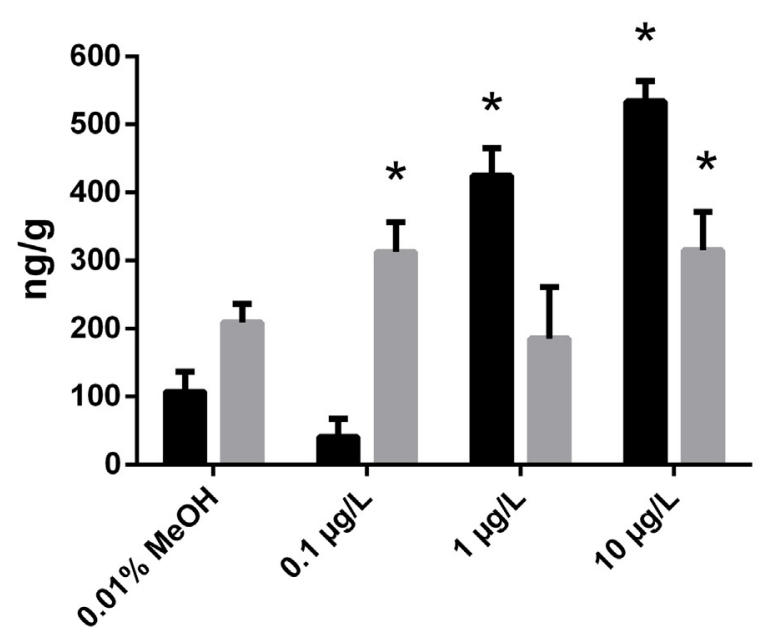

$20^{\circ} \mathrm{C}-\mathrm{T} 3$

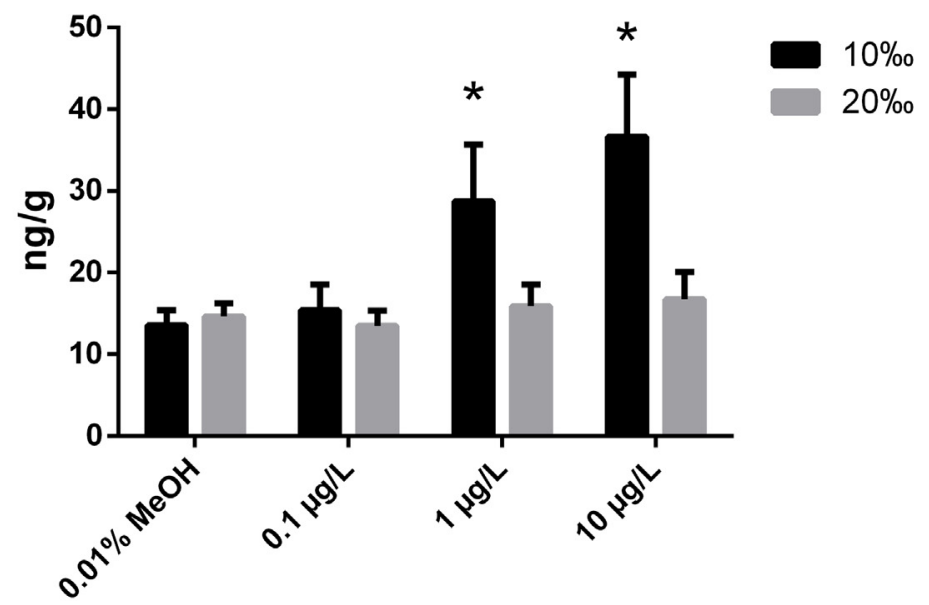

$20^{\circ} \mathrm{C}-\mathrm{T} 4$

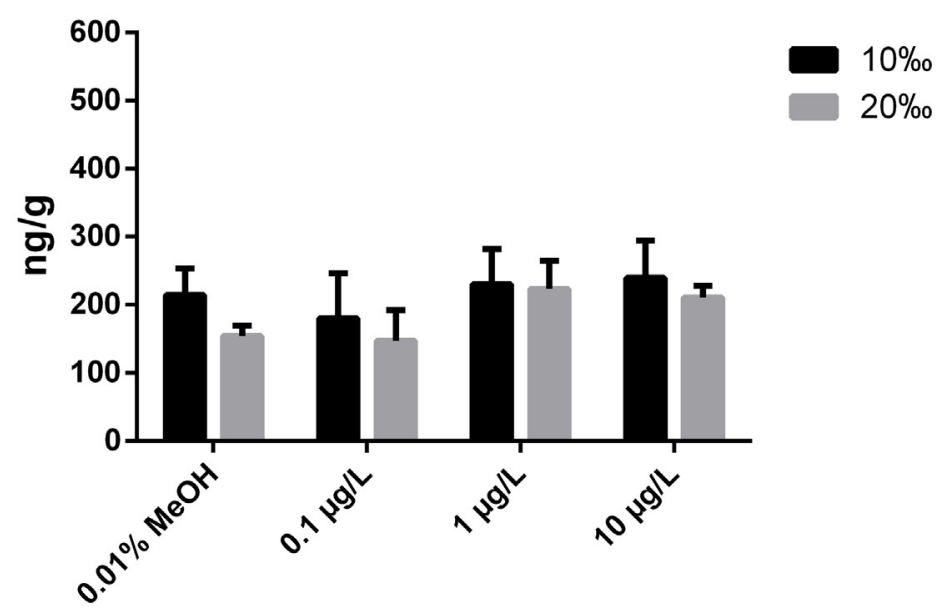

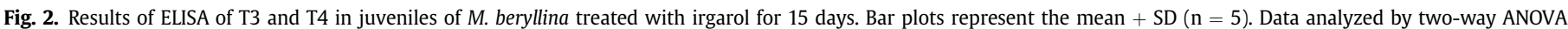
followed by Dunnett's test comparing each group with $0.01 \% \mathrm{MeOH}\left({ }^{*} \mathrm{p}<0.05\right)$.

T4 may enhance formation of T3 by Dio1 in the peripheral tissues, while the increased transcripts of Dio3 at $20 \%$ can be associated with the T3 catabolism in order to restore $\mathrm{TH}$ homeostasis. In the treatments at $20^{\circ} \mathrm{C}$ the upregulated expression of Dio1 may explain the increase of T3 (Bianco and Kim, 2006; Jarque and Piña, 2014).

The expression of thyroid ( $\alpha$ and $\beta$ ) and growth hormone receptors were analyzed. Treatments at $10{ }^{\circ} \mathrm{C}$ and $10 \%$ reduced the transcripts of TR $\alpha$ at $0.1 \mu \mathrm{g} / \mathrm{L}$ and GHR at $1.0 \mu \mathrm{g} / \mathrm{L}$, while the exposure at $20 \%$ decreased the transcripts of TR $\alpha$ and GHR in both concentrations (Fig. 3). Treatments with irgarol at $20^{\circ} \mathrm{C}$ changed the expression at $10 \%$ increasing TR $\beta(1.0 \mu \mathrm{g} / \mathrm{L})$ and Dio1 (0.1 and $1.0 \mu \mathrm{g} / \mathrm{L})$. Irgarol at $0.1 \mu \mathrm{g} / \mathrm{L}$ combined with $20 \%$ of salinity increased the expression of TR $\alpha$, GHR and decreased TR $\beta$. Fish exposed to $1 \mu \mathrm{g} / \mathrm{L}$ of irgarol reduced the expression of GHR (Fig. 4).

The actions of THs are mediated by binding to their specific nuclear thyroid receptors (TRs) which act as specific transcription factors of the thyroid system (Yamano and Miwa, 1998; Nelson and Habibi, 2009). In the same way, growth hormone (GH) has an essential role controlling fish growth and is produced by the adenohypophysis after binding to growth receptors (GHR) in target tissues (Gabillard et al., 2003; Deane and Woo, 2009). Gene expression of $\operatorname{TR} \alpha$ and TR $\beta$ were increased in larvae of K. marmoratus exposed to BDE-47 as a compensatory effect caused by the balancing feedback of TH homeostasis (Dong et al., 2013). On the other hand, decreases in the transcription of both TRs was reported in larval stage of the big head carp Hypophthalmichthys nobilis treated with arsenite (AsIII) and arsenate (AsV) (Sun et al., 2016) and in zebrafish created with the fungicide triadimefon (Liu et al., 2011). Exposure of Japanese medaka O. latipe for five months to $100 \mathrm{mg} / \mathrm{L}$ of perchlorate at the higher temperature (from 26 to $33^{\circ} \mathrm{C}$ ) decreased the transcripts of TRs as an effect of T4 depletion (Lee et al., 2014). Similar patterns of TR and GHR 
$10^{\circ} \mathrm{C}-10 \%$

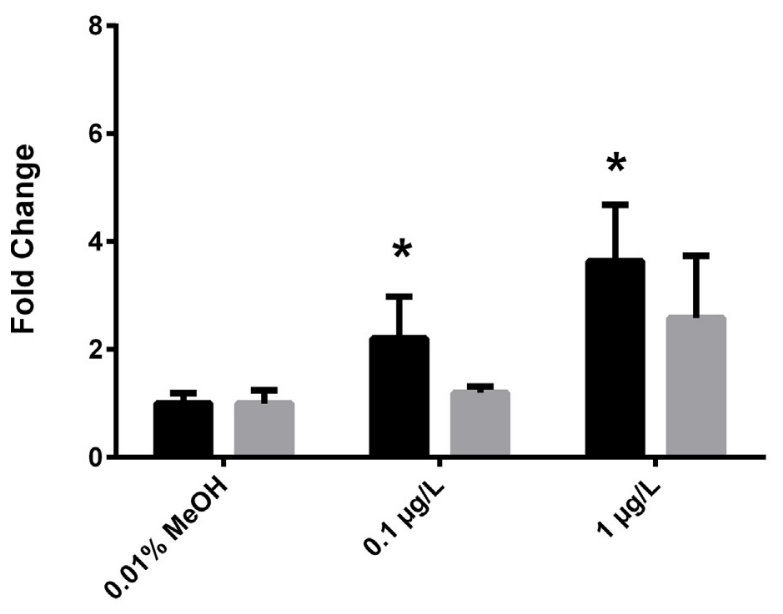

$10^{\circ} \mathrm{C}-10 \%$

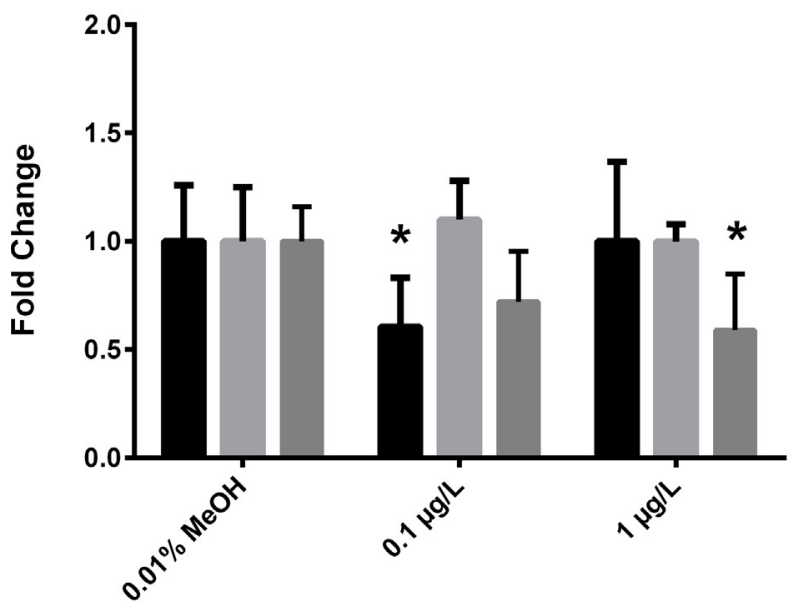

$10^{\circ} \mathrm{C}-20 \%$

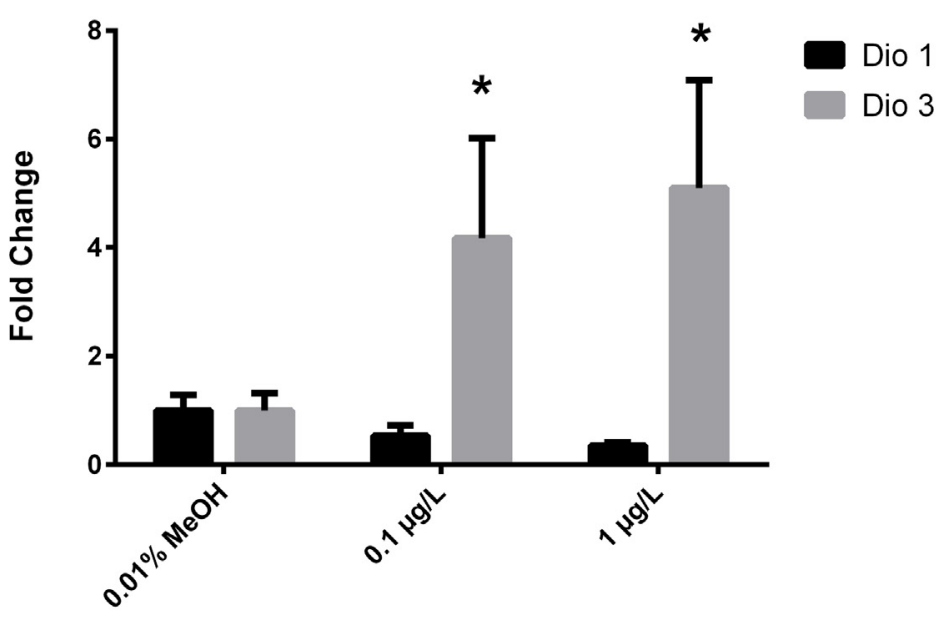

$10^{\circ} \mathrm{C}-20 \%$

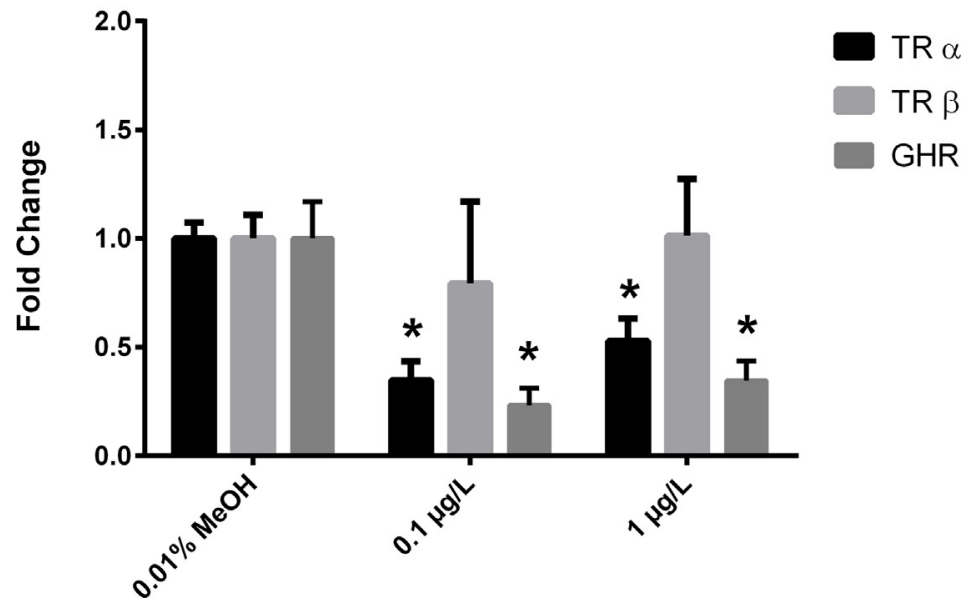

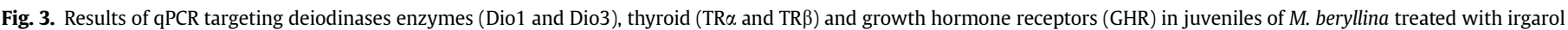

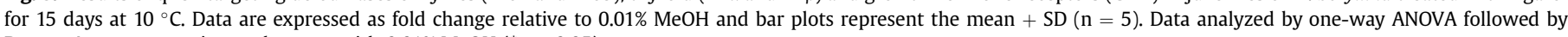
Dunnett's test comparing each group with $0.01 \% \mathrm{MeOH}\left({ }^{*} \mathrm{p}<0.05\right)$.

expression was also reported in M. beryllina after an exposure to diuron at the same levels and experimental conditions of this study (Moreira et al., 2018). For these studies it was hypothesized that the down-regulation of these receptors may be related to a response to restore the $\mathrm{TH}$ balance and highlighted the importance of further studies exploring such mechanism(s).

Fig. 5 summarizes the responses observed in $\mathrm{K}$ and the thyroidogenic responses in $M$. beryllina exposed to irgarol in a diagram based in the adverse outcome pathway (AOP) approach (Ankley et al., 2010). In the present study, irgarol augmented THs in both salinities and temperature affected only T3 levels. Deiodination pathways were triggered and $\mathrm{TH}$ and $\mathrm{GH}$ receptors were downregulated as a response to balance $\mathrm{TH}$ levels. Condition factor was also affected following the effects on $\mathrm{TH}$. These findings are similar with the responses caused by diuron in M. beryllina (Moreira et al., 2018) suggesting that these two biocides, which act by blocking PSII, induce the same mode of action in the thyroid system. Regarding the ecological relevance of the responses, silversides are a relevant group in estuarine and marine ecosystems due to their limited period of lifespan and rapid development, with annual life cycles. Juveniles present accelerated somatic growth reaching almost $30 \%$ of their biomass during the first 4 months of age (Conover and Ross, 1982; Huber and Bengtson, 1999; Chizinski et al., 2007). Silverside populations are numerous and spend most of its early life stages in shallow inland waters and after that, they migrate to coastal waters. Rapid growth coupled with this migration strategy indicates that this species is a primary source of biomass and energy exported from inner areas of the estuary to coastal zones (Conover and Ross, 1982). Consequently, impairment of $\mathrm{K}$ and growth may alter this ecological dynamic in estuarine systems.

\section{Conclusions}

Impacts on thyroid hormone homeostasis were observed in $M$. beryllina induced by the biocide irgarol at two salinities ( 10 and $20 \%$ ) and temperatures ( 10 and $20^{\circ} \mathrm{C}$ ). Since the thyroid system controls development and growth of fish, thyroid disrupting effects caused by Irgarol in $M$. beryllina can affect not only individual fish but also the population and its ecological function. Our results also 
$20^{\circ} \mathrm{C}-10 \%$

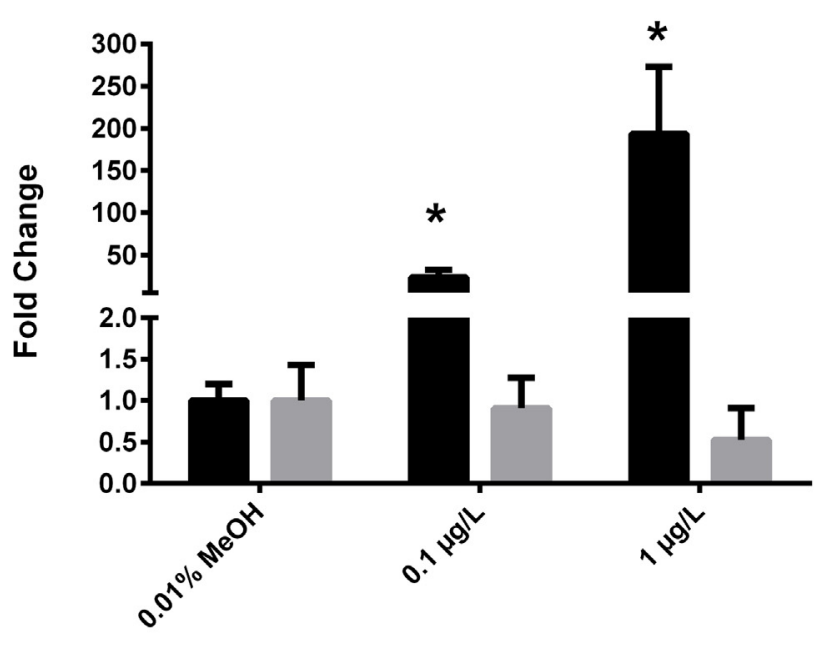

$20^{\circ} \mathrm{C}-10 \%$

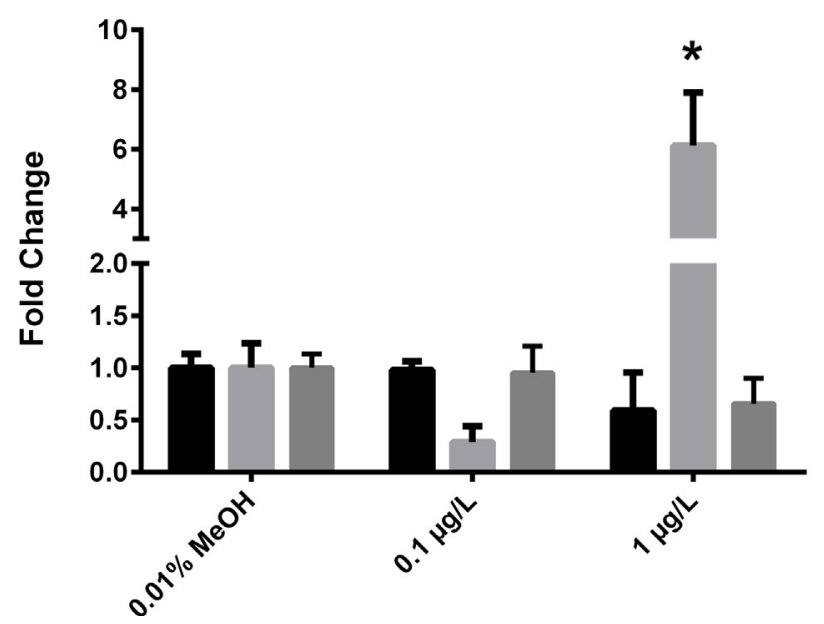

$20^{\circ} \mathrm{C}-20 \%$

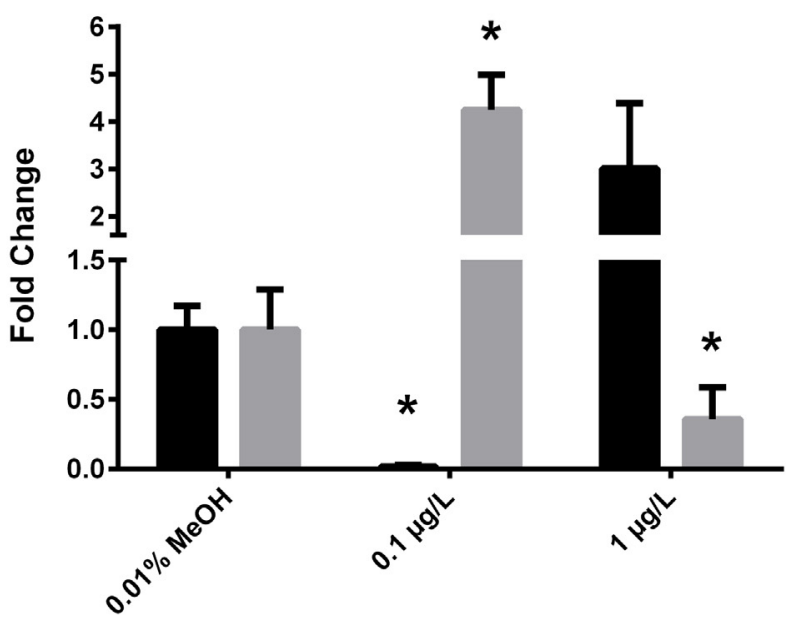

Dio 1

Dio 3

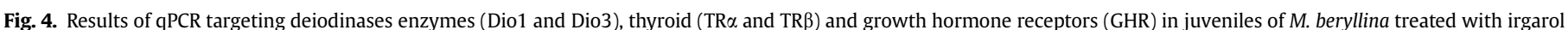

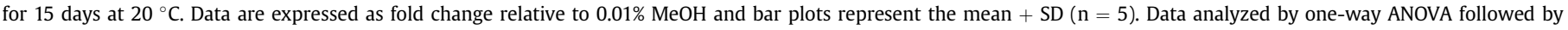
Dunnett's test comparing each group with $0.01 \% \mathrm{MeOH}\left({ }^{*} \mathrm{p}<0.05\right)$.

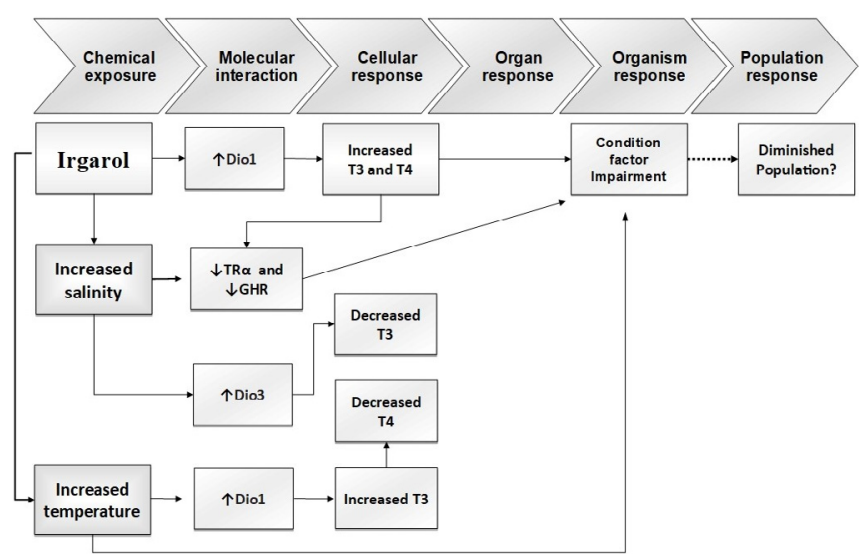

Fig. 5. Summary of the effects assessed in M. beryllina exposed to irgarol expressed as a potential adverse outcome pathway. showed that natural variations in environmental variables or induced by climate change should be addressed in risk assessment of chemicals in systems impacted by climate.

\section{Acknowledgments}

This investigation was funded by São Paulo State Research Foundation (FAPESP, Brazil) [grant number \#2016/01091-8] and also by the Research Allocation Program of the Agricultural Experiment Station (University of California Riverside). We kindly acknowledge the assistance of Dr. Susanne M. Brander and Dr. Richard E. Connon for contributing with the sequences used for primer design.

\section{References}

Ali, H.R., Ariffin, M.M., Sheikh, M.A., Shazili, N.A.M., Bachok, Z., 2015. Toxicological studies of Irgarol-1051 and its effects on fatty acid composition of Asian seabass, Lates calcarifer. Reg. Stud. Mar. Sci. 2, 171-176.

Ankley, G.T., Bennett, R.S., Erickson, R.J., Hoff, D.J., Hornung, M.W., Johnson, R.D., Mount, D.R., Nichols, J.W., Russom, C.I., Schmieder, P.K., Serrrano, J.A., Tietge, J.E., 
Villeneuve, D.I., 2010. Adverse outcome pathways: a conceptual framework to support ecotoxicology research and risk assessment. Environ. Toxicol. Chem. 29, 730-741.

Bao, V.W.W., Leung, K.M.Y., Qiu, J., Lam, M.H.W., 2011. Acute toxicities of five commonly used antifouling booster biocides to selected subtropical and cosmopolitan marine species. Mar. Pollut. Bull. 62, 1147-1151.

Bao, V.W.W., Leung, K.M.Y., Lui, G.C.S., Lam, M.H.W., 2013. Acute and chronic toxicities of Irgarol alone and in combination with copper to the marine copepod Tigriopus japonicus. Chemosphere 90, 1140-1148.

Bianco, A.C., Kim, B.W., 2006. Deiodinases: implications of the local control of thyroid hormone action. J. Clin. Invest. 116, 2571-2579.

Blanton, M.L., Specker, J.L., 2007. The hypothalamic-pituitary-thyroid (HPT) axis in fish and its role in fish development and reproduction. Crit. Rev. Toxicol. 37, 97-115.

Bolger, T., Connolly, P.L., 1989. The selection of suitable indices for the measurement and analysis of fish condition. J. Fish. Biol. 34, 171-182.

Brander, S.M., Jeffries, K.M., Cole, B.J., DeCourten, B.M., White, J.A., Hasenbein, S., Fangue, N.A., Connon, R.E., 2016. Transcriptomic changes underlie altered egg protein production and reduced fecundity in an estuarine model fish exposed to bifenthrin. Aquat. Toxicol. 174, 247-260.

Castro, I.B., Westphal, E., Fillmann, G., 2011. Tintas anti-incrustantes de terceira geração: novos biocidas no ambiente aquático. Quim. Nova 34, 1021-1031.

Chambers, L.D., Stokes, K.R., Walsh, F.C., Wood, R.J.K., 2006. Modern approaches to marine antifouling coatings. Surf. Coating. Technol. 201, 3642-3652.

Chen, R., Yuan, L., Zha, J., Wang, Z., 2017. Developmental toxicity and thyroid hormone-disrupting effects of 2,4-dichloro-6-nitrophenol in Chinese rare minnow (Gobiocypris rarus). Aquat. Toxicol. 185, 40-47.

Chizinski, C.J., Huber, C.G., Longoria, M., Pope, K.L., 2007. Intraspecific resource partitioning by an opportunistic strategist, inland silverside Menidia beryllina. J. Appl. Ichthyol. 23, 147-151.

Cima, F., Ballarin, L., 2012. Immunotoxicity in ascidians: antifouling compounds alternative to organotins III - the case of copper(I) and Irgarol 1051. Chemosphere 89, 19-29.

Cloern, J.E., Knowles, N., Brown, L.R., Cayan, D., Dettinger, M.D., Morgan, T.L., Schoellhamer, D.H., Stacey, M.T., van der Wegen, M., Wagner, R.W., Jassby, A.D., 2011. Projected evolution of California's san Francisco bay-delta-river system in a century of climate change. PLoS One. https://doi.org/10.1371/journal.pone. 0024465 .

Cole, B.J., Brander, S.M., Jeffries, K.M., Hasenbein, S., He, G., Denison, M.S., Fangue, N.A., Connon, R.E., 2016. Changes in Menidia beryllina gene expression and in vitro hormone-receptor activation after exposure to estuarine waters near treated wastewater outfalls. Arch. Environ. Contam. Toxicol. 71, 210-223.

Conover, D.O., Ross, M.R., 1982. Patterns in seasonal abundance, growth and biomass of the atlantic silverside, Menidia menidia, in a new england estuary. Estuaries 5, 275-286.

Cyr, D.G., Idler, D.R., Audet, C., McLeese, J.M., Eales, J.G., 1998. Effects of long-term temperature acclimation on thyroid hormone deiodinase function, plasma thyroid hormone levels, growth, and reproductive status of male atlantic cod, Gadus morhua. Gen. Comp. Endocrinol. 109, 24-36.

Deane, E.E., Woo, N.Y.S., 2009. Modulation of fish growth hormone levels by salinity, temperature, pollutants and aquaculture related stress: a review. Rev. Fish Biol. Fish. 19, 97-120.

Dong, W., Macaulay, L.J., Kwok, K.W.H., Hinton, D.E., Stapleton, H.M., 2013. Using whole mount in situ hybridization to examine thyroid hormone deiodinase expression in embryonic and larval zebrafish: a tool for examining OH-BDE toxicity to early life stages. Aquat. Toxicol. 132-133, 190-199.

Ebert, E., Dumford, S.W., van Assche, C.J., Warwick, D.D., 1976. Effects of triazine herbicides on the physiology of plants. In: Gunther, F.A., Gunther, J.D. (Eds.), Residue Reviews. Reviews of Environmental Contamination and Toxicology (Continuation of Residue Reviews), vol. 65. Springer, New York, pp. 1-98.

Freitas, J.S., Kupsco, A., Diamante, G., Felicio, A.A., Almeida, E.A., Schlenk, D., 2016. Influence of temperature on the thyroidogenic effects of diuron and its metabolite 3,4-DCA in tadpoles of the american bullfrog (Lithobates catesbeianus). Environ. Sci. Technol. 50, 13095-13104.

Gabillard, J.C., Weil, C., Rescan, P.Y., Navarro, I., Gutiérrez, J., Le Bail, P.Y., 2003. Environmental temperature increases plasma GH levels independently of nutritional status in rainbow trout (Oncorhynchus mykiss). Gen. Comp. Endocrinol. 133, 233-242.

Gleason, T.R., Bengtson, D.A., 1996. Growth, survival and size-selective predation mortality of larval and juvenile inland silversides, Menidia beryllina (Pisces; Atherinidae). J. Exp. Mar. Biol. Ecol. 199, 165-177.

Hall, J.L.W., Killen, W.D., Anderson, R.D., Gardinali, P.R., Balcomb, R., 2005. Monitoring of Irgarol 1051 concentrations with concurrent phytoplankton evaluations in East Coast areas of the United States. Mar. Pollut. Bull. 50, 668-681.

Hall Jr., L.W., Killen, W.D., Anderson, R.D., Balcomb, R., Gardinali, P., 2009. Ecological risk of Irgarol 1051 and its major metabolite in coastal California marinas and reference areas. Mar. Pollut. Bull. 58, 702-710.

Huber, M., Bengtson, D.A., 1999. Interspecific differences in growth and reproductive tissues during the breeding season in Menidia menidia and M. beryllina. J. Fish. Biol. 55, 274-287.

Jarque, S., Piña, B., 2014. Deiodinases and thyroid metabolism disruption in teleost fish. Environ. Res. 135, 361-375.

Kang, H., Lee, Y.H., Kim, B., Kim, I., Jeong, J., Lee, J., 2017. Adverse effects of BDE-47 on in vivo developmental parameters, thyroid hormones, and expression of hypothalamus-pituitary-thyroid (HPT) axis genes in larvae of the self-fertilizing fish Kryptolebias marmoratus. Chemosphere 176, 39-46.

Keller, V.D.J., Lloyd, P., Terry, J.A., Williams, R.J., 2015. Impact of climate change and population growth on a risk assessment for endocrine disruption in fish due to steroid estrogens in England and Wales. Environ. Pollut. 197, 262-268.

Konstantinou, I.K., Albanis, T.A., 2004. Worldwide occurrence and effects of antifouling paint booster biocides in the aquatic environment: a review. Environ. Int. 30, 235-248.

Lee, S., Ji, K., Choi, K., 2014. Effects of water temperature on perchlorate toxicity to the thyroid and reproductive system of Oryzias latipes. Ecotoxicol. Environ. Saf. 108, 311-317.

Little, A.G., Kunisue, T., Kannan, K., Seebacher, F., 2013. Thyroid hormone actions are temperature-specific and regulate thermal acclimation in zebrafish (Danio rerio). BMC Biol. https://doi.org/10.1186/1741-7007-11-26.

Liu, S., Chang, J., Zhao, Y., Zhu, G., 2011. Changes of thyroid hormone levels and related gene expression in zebrafish on early life stage exposure to triadimefon. Environ. Toxicol. Pharmcol. 32, 472-477.

MacKenzie, D.S., Jones, R.A., Miller, T.C., 2009. Thyrotropin in teleost fish. Gen. Comp. Endocrinol. 161, 83-89.

Mai, H., Morin, B., Pardon, P., Gonzalez, P., Budzinski, H., Cachot, J., 2013. Environmental concentrations of irgarol, diuron and S-metolachlor induce deleterious effects on gametes and embryos of the Pacific oyster, Crassostrea gigas. Mar. Environ. Res. 89, 1-8.

Middaugh, D.P., Hemmer, M.J., 1992. Reproductive ecology of the inland silverside, Menidia beryllina, (pisces: atherinidae) from blackwater bay, Florida. Copeia 1, 53-61.

Mochida, K., Fujii, K., 2009. Further effects of alternative biocides on aquatic organisms. In: Arai, T., Harino, H., Ohji, M., Langston, W.J. (Eds.), Ecotoxicology of Antifouling Biocides. Springer, Tokyo, p. 383.

Moreira, L.B., Diamante, G., Giroux, M., Coffin, S., Xu, E.G., Abessa, D.M.S., Schlenk, D., 2018. Impacts of salinity and temperature on the thyroidogenic effects of the biocide diuron in Menidia beryllina. Environ. Sci. Technol. https://doi.org/10. 1021/acs.est.7b04970.

Nelson, E.R., Habibi, H.R., 2009. Thyroid receptor subtypes: structure and function in fish. Gen. Comp. Endocrinol. 161, 90-96.

Nieves-Puigdoller, K., Björnsson, B.T., McCormick, S.D., 2007. Effects of hexazinone and atrazine on the physiology and endocrinology of smolt development in Atlantic salmon. Aquat. Toxicol. 84, 27-37.

Orozco, A., Valverde, R.C., 2005. Thyroid hormone deiodination in fish. Thyroid 15, 799-813.

Perina, F.C., Abessa, D.M.S., Pinho, G.L.L., Fillmann, G., 2011. Comparative toxicity of antifouling compounds on the development of sea urchin. Ecotoxicology 20, 1870-1880.

Peter, M.C.S., 2011. The role of thyroid hormones in stress response of fish. Gen. Comp. Endocrinol. 172, 198-210.

Peter, M.C.S., Leji, J., Peter, V.S., 2011. Ambient salinity modifies the action of triiodothyronine in the air-breathing fish Anabas testudineus Bloch: effects on mitochondria-rich cell distribution, osmotic and metabolic regulations. Gen. Comp. Endocrinol. 171, 225-231.

Pfaffl, M.W., 2001. A new mathematical model for relative quantification in realtime RT-PCR. Nucleic Acids Res. https://doi.org/10.1093/nar/29.9.e45.

Power, D.M., Llewellyn, L., Faustino, M., Nowell, M.A., Björnsson, B.Th., Einarsdottir, I.E., Canario, A.V.M., Sweeney, G.E., 2001. Thyroid hormones in growth and development of fish. Comp. Biochem. Phys. C 130, 447-459.

Rejitha, V., Peter, V.S., Peter, M.C.S., 2009. Short-term salinity acclimation demands thyroid hormone action in climbing perch (Anabas testudineus, Bloch). J. Endocrinol. Reprod. 13, 63-72.

Saka, M., Tada, N., Kamata, Y., 2018. Chronic toxicity of 1,3,5-triazine herbicides in the postembryonic development of the western clawed frog Silurana tropicalis. Ecotoxicol. Environ. Saf. 147, 373-381.

Sapozhnikova, Y., Pennington, P., Wirth, E., Fulton, M., 2009. Fate and transport of Irgarol 1051 in a modular estuarine mesocosm. J. Environ. Monit. 11, 808-814.

Sapozhnikova, Y., Wirth, E., Schiff, K., Fulton, M., 2013. Antifouling biocides in water and sediments from California marinas. Mar. Pollut. Bull. 69, 189-194.

Schiedek, D., Sundelin, B., Readman, J.W., Macdonald, R.W., 2007. Interactions between climate change and contaminants. Mar. Pollut. Bull. 54, 1845-1856.

Sun, H.-J., Xiang, P., Tang, M.-H., Sun, L., Ma, L.Q., 2016. Arsenic impacted the development, thyroid hormone and gene transcription of thyroid hormone receptors in bighead carp larvae (Hypophthalmichthys nobilis). J. Hazard Mater. 303, 76-82.

Thomas, K.V., Brooks, S., 2010. The environmental fate and effects of antifouling paint biocides. Biofouling 26, 73-88.

Thomas, K.V., McHugh, M., Waldock, M., 2002. Antifouling paint booster biocides in UK coastal waters: inputs, occurrence and environmental fate. Sci. Total Environ. 293, 117-127.

Tukey, J.W., 1977. Exploratory Data Analysis. Addison-Wesely, Boston, U.S.

USEPA, 2002. United States environmental protection agency. In: Inland Silverside, Menidia Beryllina, Larval Survival and Growth; Chronic Toxicity. USEPA, Office of Water, Washington, DC. Method 1006.0 EPA-821-r-02-014.

Velisek, J., Stara, A., Machova, J., Svobodova, Z., 2012a. Effects of long-term exposure to simazine in real concentrations on common carp (Cyprinus carpio L.). Ecotoxicol. Environ. Saf. 76, 79-86.

Velisek, J., Stara, A., Machova, J., Dvorak, P., Zuskova, E., Prokes, M., Svobodova, Z. 2012b. Effect of terbutryn at environmental concentrations on early life stages of common carp (Cyprinus carpio L.). Pestic. Biochem. Physiol. 102, 102-108.

Wagner, R., Stacey, M., Brown, L., Dettinger, M., 2011. Statistical models of 
temperature in the Sacramento-San Joaquin Delta under climate-change scenarios and ecological implications. Estuar. Coast 34, 544-556.

Westlund, P., Yargeau, V., 2017. Investigation of the presence and endocrine activities of pesticides found in wastewater effluent using yeast-based bioassays. Sci.
Total Environ. 607-608, 744-751.

Yamano, K. Miwa, S., 1998. Differential gene expression of thyroid hormone receptor $\alpha$ and $\beta$ in fish development. Gen. Comp. Endocrinol. 109, 75-85. 